\title{
THE USING OF 4D FLASHCARD WITH KINESTHETIC STUDENTS TO INCREASE SPEAKING SKILLS
}

\author{
Hardianti Hamzah ${ }^{1}$, Nurhamdah ${ }^{2}$,Magdahalena ${ }^{3}$ \\ English Program, Tarbiyah Faculty, State Islamic Institute of Parepare ${ }^{123}$ \\ Hardiantihamzah5@gmail.com ${ }^{1}$
}

\begin{abstract}
The using of technology had developed especially in education. Even though it was had a high technology, some of the teachers did not use it. In this case, this research was introduced a new application media in learning process and it is called Octaland 4D. This application is made by Octagon studio with purposing to give a benefit in education by using 4D flashcards. The research used an experimental design one group pre-test and post-test. The population in this research was the first-year kinesthetic students, in academic year 2017. The samples of this research were the first-year kinesthetic students. The technique of sampling used total sampling, the writer took all population the first-year kinesthetic students to be a sample and the data was analyzed into percentage, mean score analyzed and the value of the t-test. The result of the data analysis showed that the students' achievement on the post-test was higher that on the pre-test. Moreover, based on the analysis the researcher found that the students speaking skill in English was increased significantly. This research gave a suggestion that using 4D flashcard as the media is a good way in learning process in speaking English.
\end{abstract}

Keywords:Speaking Skills,4D Flashcard, The Kinesthetic Students

\section{Introduction}

The technology has developed especially in education. The evidence of the technology effect is the developing application based on education. Even though it is had a high application, some of the teachers did not apply it at the school. In fact, some of the teachers have tough monotonous in learning process. Furthermore, the teachers did not use the effectiveness media to the students and this situation made the students bored to study about the subject especially in English.

In this case to increase the student's intention for studying, the teacher should understand about the starting point of the lesson and student's need because it could 
not be working well if the teachers did not understand about the situation of the students. In addition, it was important to know the way for disappeared the boredom of the students.

Moreover, to minimizing this situation, the teacher may give a new application media in learning process and it is called Octaland 4D. This application is made by Octagon studio with purposing to give an education by using fourdimensionflashcard. It needed a mobile phone to show four-dimensionflashcard. In other words, it was one of media for learning process by using high technology. This application made the learning process more attractive, because the students used 4D flashcard as a media.

\section{Method}

This research is designed for pre-experimental method (the one group pre-test post-test). The location of the research in MA DDI Lil Banat Parepare focusing to the first year on academic year 2016/2017 and the duration was two months. The total number of population was the kinesthetic students consisted of 18 students. It had two classes, they were $X 1$ and $X 2$. Because the objective of the research was to find out the increase of the kinesthetic students' speaking skill by using 4D flashcard, the researcher used total sampling of the first-year kinesthetic students of MA DDI LIL BANAT. In other words, the sample of this research was 8 students from class $\mathrm{X} 1$ and 10 students $X 2$. In this research the researcher applied three kinds of instrument namely test, observation and questionnaire.

Furthermore, the procedure of collecting data in this research used three steps. The first step was Pre-Test, the researcher gave the students speaking test to identify the students' speaking skill. After giving a pre-test, the researcher gave the treatment in six meetings, each meeting ran for $1 \times 90$ minutes. In this step 4D flashcard is applied in some activities such as connecting card,guessing picture and battle game.

Moreover, technique of data analysisis collected through the test analyze quantitative in percentage to measure the students' achievement. This quantitative analysis employed statically calculation to the test the hypothesis. To find 
outstudents' speaking skill, it was viewed from the four components, they were: fluency, accuracy, content, and pronunciation. Then, the next step was to finding out the mean score of pre-test and posttest, the difference by calculating the T-test value and finding out the standard deviation.

In addition, to analyze the students' response, the researcher gave questionnaire to the students. The research had 10 positive and 10 negative statements. The researcher used Liker scale that contained tent category of positive and negative statements consisted of strongly agree(SA), agree(A), undecided(U), disagree(D), strongly disagree(SD).

Therefore, if a student answered the ten positive statements with strongly agree and with all ten negative ones with strongly disagree, the students got one hundred and if a student answered the ten negative statements with all ten negative ones with strongly agree, the students got twenty. The questionnaire gets five categories, the interval would be used to determine category was twenty.

\section{Result}

The findings in detail based on the research questions. Firstly, to knew the using of four-dimension cards in increasing the students' speaking skill by using speaking test. Secondly, to knew the students' response toward speaking by using questionnaire.

Students' Skills on Speaking

Table 1.The students' score of pre-test

\begin{tabular}{|c|c|c|c|c|c|c|}
\hline \multirow{2}{*}{ No. } & \multicolumn{4}{|c|}{ The Student Score } & \multirow{2}{*}{ Total } & \multirow{2}{*}{ Score } \\
\hline & Fluency & Accuracy & Content & Pronunciation & & \\
\hline 1 & 5 & 2 & 3 & 2 & 12 & 48 \\
\hline 2 & 1 & 3 & 2 & 3 & 9 & 36 \\
\hline 3 & 4 & 2 & 4 & 1 & 11 & 44 \\
\hline 4 & 1 & 3 & 2 & 1 & 7 & 28 \\
\hline 5 & 2 & 1 & 1 & 2 & 6 & 24 \\
\hline 6 & 1 & 1 & 2 & 1 & 5 & 20 \\
\hline 7 & 2 & 1 & 3 & 1 & 7 & 28 \\
\hline
\end{tabular}




\begin{tabular}{ccccccc}
8 & 1 & 2 & 1 & 2 & 12 & 36 \\
9 & 2 & 1 & 1 & 3 & 7 & 28 \\
10 & 2 & 1 & 1 & 2 & 6 & 24 \\
11 & 2 & 4 & 1 & 1 & 8 & 32 \\
12 & 1 & 4 & 1 & 2 & 8 & 32 \\
13 & 1 & 2 & 2 & 1 & 6 & 24 \\
14 & 2 & 1 & 3 & 1 & 7 & 28 \\
15 & 1 & 1 & 2 & 2 & 6 & 24 \\
16 & 2 & 4 & 1 & 1 & 8 & 32 \\
17 & 3 & 2 & 1 & 1 & 7 & 28 \\
18 & 1 & 1 & 3 & 3 & 8 & 32 \\
\hline
\end{tabular}

(Source: Primary data processing)

Table 1 showed that the students' score of pre-test, before doing the treatment they did not have good criteria. It was proved that almost the students got two and three in fluency, accuracy, content, and pronunciation components.

Table 2 The students' score of post-test

\begin{tabular}{ccccccc}
\hline No. & \multicolumn{5}{c}{ The Criteria } & \multicolumn{2}{c}{ Total } & Score \\
\cline { 2 - 5 } 1 & Fluency & Accuracy & Content & Pronunciation & & \\
2 & 6 & 4 & 6 & 5 & 21 & 84 \\
3 & 5 & 6 & 5 & 4 & 20 & 80 \\
4 & 6 & 5 & 4 & 4 & 19 & 76 \\
5 & 3 & 2 & 5 & 4 & 14 & 56 \\
6 & 6 & 6 & 7 & 5 & 24 & 68 \\
7 & 3 & 5 & 5 & 2 & 15 & 60 \\
8 & 5 & 6 & 4 & 4 & 21 & 84 \\
9 & 5 & 4 & 5 & 3 & 17 & 80 \\
10 & 4 & 3 & 6 & 4 & 15 & 84 \\
11 & 5 & 4 & 3 & 3 & 14 & 76 \\
12 & 8 & 5 & 4 & 5 & 19 & 76 \\
13 & 4 & 4 & 6 & 3 & 18 & 72 \\
14 & 3 & 4 & 5 & 4 & 17 & 68 \\
15 & 3 & 5 & 4 & 4 & 16 & 64 \\
16 & 3 & 3 & 5 & 3 & 14 & 88 \\
17 & 4 & 4 & 5 & 5 & 17 & 68 \\
18 & 4 & 7 & 3 & 4 & 16 & 56 \\
\hline
\end{tabular}

(Source: Primary data processing) 
Table 2 showed the students' score of post-test was higher. It proved that after doing treatment the students were brave to speak English. In other words, the students' speaking skills had good criteria. It can be seen that almost the students got five and six in criteria of fluency, accuracy, content, and pronunciation components.

Table 3 The percentage of pre-test

\begin{tabular}{clccc}
\hline No & Classification & Score Interval & Frequency & \% \\
\hline 1. & Excellent & $81-100$ & 0 & 0 \\
2. & Good & $66-80$ & 0 & 0 \\
3. & Fair & $56-65$ & 0 & 0 \\
4. & Poor & $41-55$ & 2 & 11,11 \\
5. & Very Poor & $\leq 40$ & 16 & 88,89 \\
\hline & & & 18 & 100 \\
\hline
\end{tabular}

Table 3 showed that the average of student's speaking skill was very poor. It meant that the students had low skill in speaking before doing treatment.

Table 4 The percentage of post-test

\begin{tabular}{clccc}
\hline No & Classification & Score Interval & Frequency & \% \\
\hline 1. & Excellent & $81-100$ & 4 & 22,22 \\
2. & Good & $66-80$ & 10 & 55,56 \\
3. & Fair & $56-65$ & 4 & 22,22 \\
4. & Poor & $41-55$ & 0 & 0 \\
5. & Very Poor & $\leq 40$ & 0 & 0 \\
\hline & & & 18 & 100 \\
\hline
\end{tabular}

Table 4 above explained that the average of the student's speaking skill after giving treatment was good. It can be seen by considering the percentage above.

Based on the table of pretest and posttest, it can be concluded that the percentage both of pretest and posttest had increased. It proved that in pretest the classification of the students were dominant on the under level. Conversely in posttest, almost the students' classification on the better level. 
7nspiring: English Education Journal

Volume 2 No I Maret 2019

\section{Mean Score and Standard Deviation of Pre-test and Post-test}

Before determine mean score of students' speaking skill at the pre-test and post-test and standard deviation, the researcher showed the students' scores in the following table:

Table 5 The Significance between the students' pre-test and post test

\begin{tabular}{ccccccc}
\hline No. & Pre $\left(\mathbf{X}_{\mathbf{1}}\right)$ & $\left(\mathbf{X}_{\mathbf{1}}\right)^{\mathbf{2}}$ & Post $\left(\mathbf{X}_{\mathbf{2}}\right)$ & $\left(\mathbf{X}_{\mathbf{2}}\right)^{\mathbf{2}}$ & $\mathbf{( \mathbf { D } )}$ & $\mathbf{X}_{\mathbf{2}} \mathbf{- \mathbf { X } _ { \mathbf { 1 } }}$ \\
\hline 1 & 48 & 2304 & 84 & 7056 & 36 & 1296 \\
2 & 36 & 1296 & 80 & 6400 & 44 & 1936 \\
3 & 44 & 1936 & 76 & 5776 & 32 & 1024 \\
4 & 28 & 784 & 80 & 7744 & 52 & 3600 \\
5 & 24 & 576 & 68 & 4624 & 44 & 1936 \\
6 & 20 & 400 & 60 & 3600 & 40 & 1600 \\
7 & 28 & 784 & 84 & 7056 & 56 & 3136 \\
8 & 36 & 1296 & 80 & 6400 & 44 & 1936 \\
9 & 28 & 784 & 84 & 7056 & 56 & 3136 \\
10 & 24 & 576 & 76 & 5776 & 52 & 2704 \\
11 & 32 & 1024 & 76 & 5776 & 44 & 1936 \\
12 & 32 & 1024 & 72 & 5184 & 40 & 1600 \\
13 & 24 & 576 & 68 & 4624 & 44 & 1936 \\
14 & 28 & 784 & 64 & 4096 & 36 & 1296 \\
15 & 24 & 576 & 88 & 7744 & 64 & 4096 \\
16 & 32 & 1024 & 68 & 4624 & 36 & 1296 \\
17 & 28 & 784 & 56 & 3136 & 28 & 784 \\
18 & 32 & 1024 & 80 & 6400 & 48 & 2304 \\
\hline$\sum$ & $\sum \mathrm{X}_{1}=548$ & $\sum\left(\mathrm{X}_{1}\right)^{2}=16976$ & $\sum \mathrm{X}_{2}=$ & $\sum\left(\mathrm{X}_{2}\right)^{2}=$ & $\sum \mathrm{D}=$ & $\sum \mathrm{D}^{2}=$ \\
& & 1344 & 103072 & 804 & 37552 \\
\hline
\end{tabular}

(Source: Primary data processing)

Table 5 showed details of the significance between students' pre-test and posttest. The total score of students in pretest and posttest were rise. It could be seen by considering the table above.

Table 6 The Mean Score and Standard Deviation of the students' Pre-Test and

Post-Test

\begin{tabular}{cccc}
\hline No & Test & Mean Score & Standard Deviation \\
\hline 1 & Pre-test & 30,44 & 4,15 \\
2 & Post-test & 74,67 & 12,65 \\
\hline
\end{tabular}


The data on the table above indicate that the students' speaking skill by using 4D flashcard were increased because the mean score of posttest was higher than the mean score of pre-test.

Table 7 The result of t-test and t-table value

\begin{tabular}{cc}
\hline t-test Value & t-table Value \\
\hline 19.05 & 2.110
\end{tabular}

Table 7 provided the value of the $t$-test was greater than the value of table. It described that there was significance difference in increasing speaking skill after doing treatment by using $4 \mathrm{D}$ flashcard.

Table 8 The percentage of questionnaire

\begin{tabular}{lclcc}
\hline No. & Scores & \multicolumn{1}{c}{ Category } & Frequency & \% \\
\hline 1. & $81 \%-100 \%$ & Very responsive(very positive) & 16 & 88,89 \\
2. & $61 \%-80 \%$ & Responsive(positive) & 2 & 11,11 \\
3. & $41 \%-60 \%$ & Undecided & 0 & 0 \\
4. & $21 \%-40 \%$ & Did not responsive (negative) & 0 & 0 \\
5. & $0 \%-20 \%$ & Very not responsive(very negative) & 0 & 0 \\
\hline & Total & & 18 & $100 \%$ \\
\hline
\end{tabular}

Based on table 8 above, the researcher concluded that the average of the students were positive response. It meant that the students were responsive in learning English by using 4D flashcard.

\section{Discussion}

The researcher uses 4D flashcard as an effective media to increase the kinesthetic students' speaking skills. According to Joanna flashcards can be bright and colorful and make a real impact on visual learners. Many of the activities outlined also appeal to kinesthetic learners (Joanna Budden, 2017). It can be said the media is suitable with visual and kinesthetic learners.

In addition kinesthetic learnersprefer active participants experiences such students learn best by experience and by being involvedphysically in classroom experiences (Abbas Pourhossein Gilakjani, 2017). In this case the researcher chose 4D 
flashcard as alternative for increasing the speaking skills of kinesthetic students of the tenth year of MA DDI Lil-Banat.

Moreover, the criteria of their speaking skill before the treatment were very poor. The content of the story was not good because the students had described uncompleted story. In addition, the students had poor pronunciation when speaking. Consequently, the meaning of their story was change. In addition, the students described people from the picture on the post test. As the result, almost all of the students able to describe the picture well. It can be said that the speaking skill of the students were better after applying 4D flashcard in the classroom.

In observation, the students were very responsive in learning speaking by applying 4D flashcard. There were three categories for doing observation such as active, pay attention and playing. Furthermore, it had done in six meetings of the treatment. As the result, the students showed a good responsive. For that reason, it proved that the students' response in every meeting were rise on the better level.

The number of questionnaire was 20 and it consisted of 10 positive statements and 10 negative statements. Those questionnaires were given to 18 students.That questionnaire covered general statements about students' response toward learning English by using 4D flashcard. The statements range from attention: giving information, concentration in learning, the happy feelings: enthusiastic, participation: the students' wish and take attendance.

The findings of response through questionnaire was $88,89 \%$. In other words, the average of the students had positive response on speaking after following speaking class by using 4D flashcard. Furthermore, the theory in chapter two about the advantages of 4D flashcard had relationship with the statement. The positive statement of questionnaire said that 4D flashcard was an interesting media and the students were very happy in learning English by using the media. It can be related with the theory in the advantages of 4D flashcard. It said that flashcard was ideal way to use as educational games, because colorful design attracted children and adults. For that reason, it can be said that 4D flashcard was an interesting media because of 
colorful design and the students were very happy because 4D flashcard was applied in the educational games.

\section{Conclusion}

As the end of this research, the researcher would like to give a conclusion as stated below:

The research of data analysis showed that there is a significant difference between the students speaking skills before and after learning speaking by using 4D flashcard,it was proved by the development of mean score from 30.44 on pre-test to 74.67 on post-test, while the t-test value 19.05. The research of data analysis showed that some students able to explain and speak up based on the factors of speaking by using 4D flashcard, it means that implementing media 4D flashcard able toincrease speaking skills to the first year kinesthetic students of MA DDI Lil Banat Parepare.

The research of the data of questionnaire analysis showed that the tenth year students of MA DDI LilBanatParepare were positive response about $88.89 \%$ in learning speaking by using 4D flashcard.

\section{References}

Agrawal Mayur, Adwait Kulkarni, Sneha Joshi, Nishi Tiku. 2015,"International Journal of Advance Research in Computer Science and Management Studies," vol 3 No.2.

Arikunto Suharsimi.2009,Dasar-dasar Evaluasi Pendidikan, Tenth Edition.Jakarta: PT Bumi Aksara.

Azzam Abdullah, Faisal, Muhammad Ridwan.2015,"Pembangunan Flashcard berbasis Augmented Reality untuk menunjang pembelajaran pada anak," vol 21 No.4.

Bahar Kaharuddin.2014. Interactional Speaking. Yogyakarta: Trustmedia Publishing Yogyakarta.

Brown Douglas. 2004, Language Assessment Principle and Classroom Practices.Unites states of Amerika :San Frasisco state university. 
Budden Joanna. 2017. Using Flashcard of young learners. https://www. teachingenglish.org.uk/article/using-flash-cards-young-learners $\left(24^{\text {th }}\right.$ may $)$

Cambridge Dictionary. Definition of Interest.2017.http://dictionary. Cambridge .org/ dictionary/english/interest $\left(5^{\text {th }}\right.$ march).

Celce, Murcia Marianne, Donna M.Brinton, Janet M,Goodwin. 2010, Teaching Pronunciation A Course Book And Reference Guide. New York : Cambridge University Press.

Doni, Sindu, Phalguna, Yogi. 2008, Evaluasi pendidikan. Bali : BETA.

Farah, Nasikhatun Listya Atika. 2013,'Improving The Students' English Speaking Skills Through Cue Cards Media At Grade VII of MtsN Rowokele in the academic year”.Thesis Universitas Negeri Yogyakarta.

Fattah Shiamaa.2006,"The Effectiveness of a Task- Based Instruction program in Developing the English Language Speaking Skills of Secondary Stage Students". Thesis Ain Shams University Cairo.

Felder, R. M., \& Silverman, L. K. 2017,’Learning and teaching styles in engineering education," Engineering education, vol 78 no. 7.

Gay.L.R.Educational.1981,Educational Research:Competencies for Analysis \& Application, United States ofAmerica:Florida Internasional University.

Ginusti, Gallis Nawang.2014,'’Improving The Speaking Skills Of Grade VIII Students Of SMP Negeri 2 Godean Through Pictures.” Thesis Universitas Negeri Yogyakarta.

Hycraft John. 1986, An Introduction To English Language Teaching. Harlow :Longman Group Limited.

Jabu Baso. 2007, English Language Testing. Makassar :Universitas Negeri Makassar.

Kumar Ranjit. 2011,Research Metodology a step by step guide for beginners, third Edition.New Delhi: SAGE Publications India Pvt Ltd.

Meriam Webster. Definition of Test.2017.https://www.merriamwebster .com /dictionary/test $\left(2^{\text {nd }}\right.$ February). 
Merriam-Webster Incorporated. Merriam-Webster's Pocket Dictionary.2017. https://www.merriam-webster.com/dictionary/response $\left(18^{\text {th }}\right.$ April $)$

Mulia Musda.2013,“Using Speaking Without Thinking Game To Improve Speaking Ability Of The First Year Students Of MA DDI LIL Banat Parepare”. Skripsi STAIN Parepare.

Musdalifah.2009,'Utlizing Common Classroom Expression To Improve Speaking Ability of Seventh Year Students of Smp 8nParepare”. Thesis Umpar .

NCLRC. The Essentials Of Language Teaching. 2017.http:// www.nclrc.org/ essentials/speaking/spandex.htm $\left(20^{\text {th }}\right.$ April $)$

Noor Juliansyah .2015, Metodologi Penelitian Skripsi, Tesis, Disertasi \& Karya Ilmiah. Jakarta: Prenadamedia Group.

Oktavia, Nidya Andini. 2014,"Problems Faced By English Department Students in Class Speaking Activities and their Causing Factors".Skripsi STAIN Batu sangkar.

Pandey Prabhat, Meenu Mishra Pandey. 2015, Research Methodology :Tools and Techniques .Romania:Bridge Center.

Paul David. 2003, Teaching English to Children in Asia. Hongkong: Pearson Longman Asia ELT.

Pourhossein, Gilakjani Abbas. 2012" Visual, Auditory, Kinaesthetic Learning Styles and Their Impacts on English Language Teaching, vol. 2 no. 1.

Putri, Elza Eka. 2014,’Using Cue Card Media To Imrove The Students' Speaking Ability At The Second Year Of SMK Negeri 4 Pinrang". Skripsi STAIN Parepare.

Rebecca Ezekiel. What's your personal learning style?.2017. https:// www. studyingstyle.com/ tactile-kinesthetic-learners/.(15 $5^{\text {th }}$ May)

Riduan, Akdon. 2015"Rumus dan Data dalam Analisis Statistika,Bandung:Alfabeta. Saepuddin, et.al.2013 "Pedoman Penulisan Karya Ilmiah (Makalah dan Skripsi).Edisi Revisi: STAIN Parepare. 
7nspiring: English Education Journal

Volume 2 No I Maret 2019

Sriati, Lubaitul Humaidah, Yudi Prasetyo, 2013"The Use Of Flashcard Media To Improve Students Speaking Ability, vol. 1 no. 2.

Sugiono.2011, Metode PenelitianPendidikan Pendekatan Kuantitatif Kualitatif dan $R \& D$, twelve Edition.Bandung:Alfabeta.

Supriyatna Hari. 2014,“The Effectiveness Of Guessing Game Technique In Teaching Vocabulary At Mts Darussalam”. Skripsi UIN Syarif Hidayatullah Jakarta.

\section{Appendix}

Cars 4D Flashcard

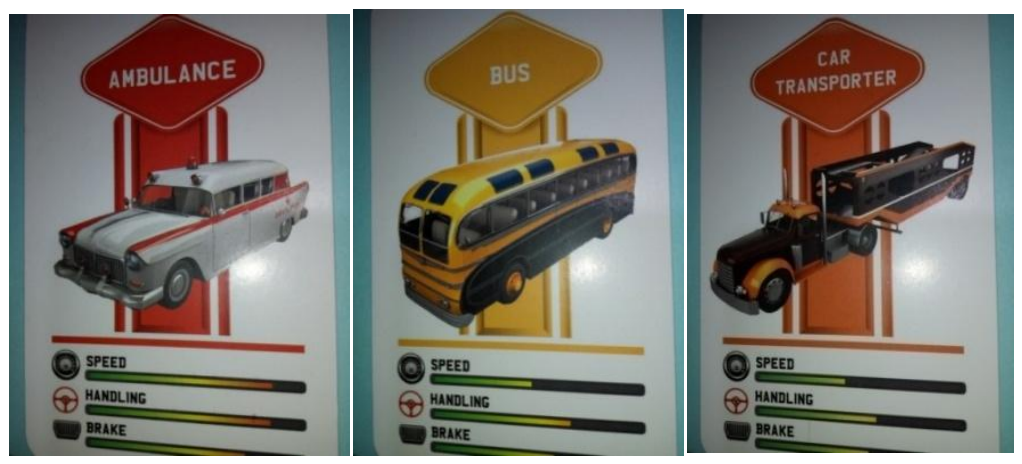

Animal 4D Flashcard

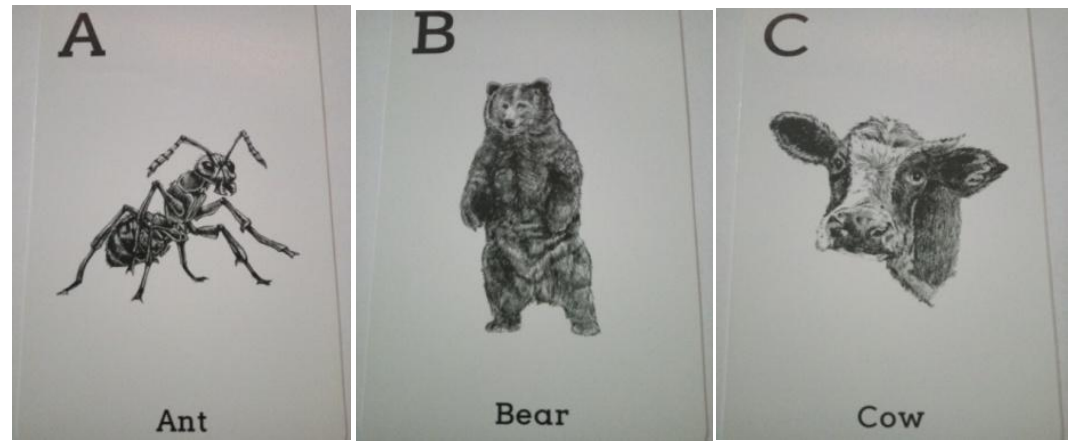

Occupation 4D Flashcard 
7nspiring: English Education Journal

Volume 2 No I Maret 2019

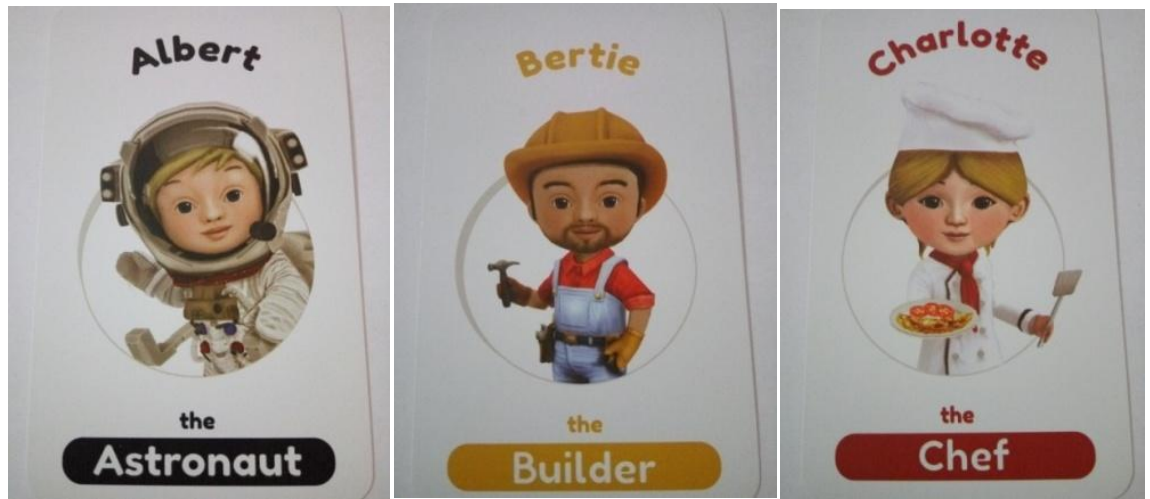

Space 4D Flashcard

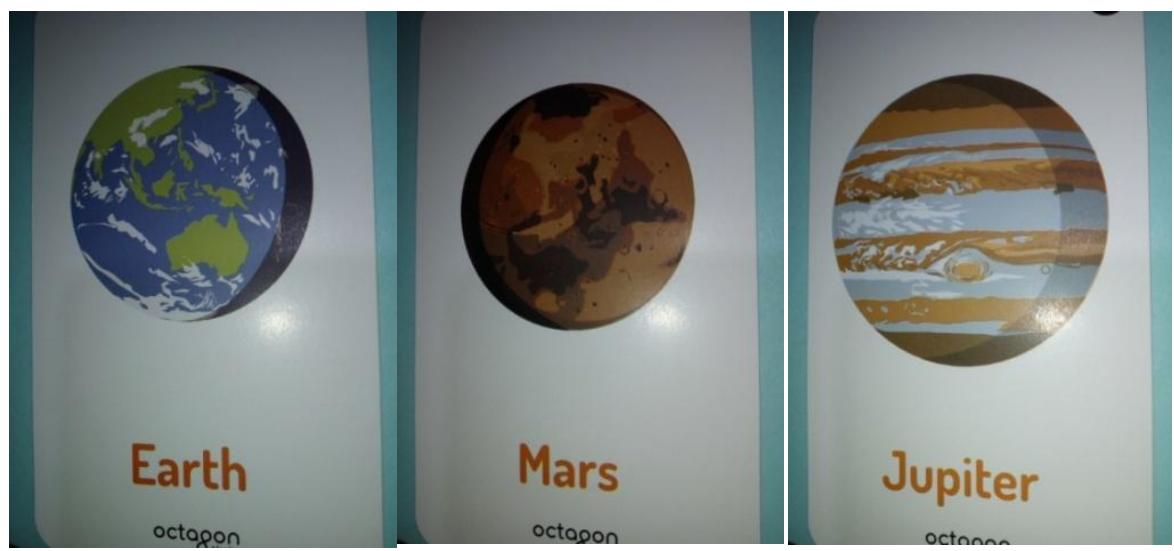

